\title{
The 15th International Geological Congress, South Africa (1929): The Resurgence of Wegener's Continental Drift Theory
}

E.T.S. de Ingenieros de Minas de Madrid-Universidad Politécnica de Madrid. Sociedad Española para la Defensa del Patrimonio Geológico y Minero (SEDPGYM). International Commission on the History of Geological Sciences (INHIGEO-IUGS).

E-mail: luisfelipe.mazadiego@upm.es; octavio.puche@upm.es

Translated from Spanish by Lilen Malugani Guillet

The 15th International Geological Congress was held in South Africa in 1929. Many interesting issues were tackled, thanks to the development of geophysical techniques, ideas about magmatic differentiation, and the origin of the Karroo System, among others. The importance of the Congress from the point of view of the history of geology lies in the fact that an 'inflection point' occurred as regards thinking about the continental drift theory that had been proposed by Wegener a few years earlier. It can be said that the contributions of Du Toit allowed a deepening in the theoretical bases of this scientific hypothesis, which celebrated its first hundred years in 2012.

\section{Preparations for the Congress}

During the 14th International Geological Congress (14th IGC), celebrated in Madrid (Spain) in 1926, it was not found possible to make a decision about the next venue owing to fact that the representatives of both Argentina and Czechoslovakia—proposed as possible candidates-indicated that their countries could not assume responsibility for the organization of such an event. In the absence of any other country offering to act as host it was decided, in a nonbiding way, to determine the venue for 1929. Almost unanimously, the participants of the Madrid Congress chose South Africa, justifying the proposal on the basis of the geological significance and mining riches of its territory. The members of the South African delegation were grateful for the confidence placed in them, though they did not formally commit to accepting it until they had had discussions with their Government.

Even so, with the object of facilitating the negotiations that were to be held in their country after the Congress, the mining engineers César Rubio Muñoz (1858-1931) (President of the 14th IGC) and Enrique Dupuy de Lome y Vidiella (1885-19??) (Secretary of the 14th IGC) prepared a draft of what was accomplished in Madrid, and, to formalize the proposal, they wrote the following letter addressed to Arthur Lewis Hall (1872-1955), who, although born in England, was a representative of the Union of South Africa at the 14th IGC:

\begin{abstract}
Dear Sir: In connection with the possibility of holding the $X V t h$ Session of the International Geological Congress at Pretoria, about which matter we recently had some conversation, I desire to say on behalf of the Geologists who form the XIVth International Geological Congress, that it would afford all of them the greatest pleasure to be the guests of the Union of South Africa. In a country where some of the most important Mining Centres in the world are found, such a meeting would undoubtedly prove an enormous success and would be of benefit not only to the visitors, but probably also to the Mining Industry; I need scarcely say that many of the remarkable mining-fields of South Africa would prove of great interest to the geologists. I should be very obliged if you would call the attention of your Government to this feeling of the Congress Members, who would very highly appreciate an invitation from the Government of the Union of South Africa, as a recognition of the important part [that] Geological Science plays in the development of South Africa's unique mineral resources (Anonymous, 1930a).
\end{abstract}

Being already in his adoptive country, Hall delivered this letter and accompanying memorandum to the members of the Government who, after several meetings, committed themselves to financially support the celebration of the Congress in South Africa. A large part of its subsequent success was due to the negotiations addressed by the mining engineer Herbert Warrington Smyth (1867-1943) (Secretary of Mines and Industries) and Colonel Frederic Hugh Page Cresswell (1866-1948) (Minister for Mines and Industries in South Africa and Commissioner of Mines for Natal). During the first phases, many businesses, professional organizations and captains of industry were already supporting the Congress (Gold Producers Committee of the Transvaal Chamber of Mines, Collieries Committee of the Transvaal Chamber of Mines, De Beers Consolidated Mines, the Pretoria Chamber of Commerce, Kimberley Town Council, etc.) and the Town Council of Pretoria promised that transportation would be without cost to the attendees, and would collaborate financially to keep the expenses of printing and editing as low as possible.

In accordance with what had been done previously, a representative of the Government of the host country, in this case James Barry Munnik (1866-1942) (Minister of External Affairs), sent a letter inviting researchers and professionals of the countries round 
the world to participate in the Congress, notifying them of the venue and the date of the scientific gathering:

I have the honour to inform you that the invitation by His Britannic Majesty's Government in the Union of South Africa to the President of the Fourteenth International Geological Congress, held in Madrid, to hold the next Congress in South Africa in 1929, was accepted by the Congress. The Fifteenth International Geological Congress will therefore be held in Pretoria, Transvaal Province, during the Month of July, 1929. The Union Government sincerely hopes that the Government of ... will be represented at this Congress, and will appreciate a favourable reply. In case of your Government should be able to be so represent, I should be glad if you would inform me of the names of the delegates who will attend the Congress. A copy of the first Circular issued on behalf of the Organising Committee is enclosed. I have the honour to be, Sir, Your obedient Servant (signed) J. B. M. Hertzog (Anonymous, 1930a).

At first it was thought that 1928 could be the year for the celebration of the 15th IGC; but after recognizing the impossibility of organizing it at such short notice, they thought of holding the meeting in 1930, but this date was discarded because it would clash with the Imperial Mining and Metallurgical Congress, to be held in South Africa that year. So the year 1929 was eventually chosen (see Figure 1). In that same year, South Africa was also going to organize another important event: the Congress of the Association for the Advancement of Science and there were scientists who participated in both events.

\section{The Organizing Committee}

Once the organization of the 15th IGC in South Africa was approved by the Prime Minister, the Council of the Geological Society of South Africa (GSSA) called a special General Meeting, to which were invited the leading members of the mining industry, civil authorities, mining engineers, geologists, etc. This meeting was held in Johannesburg on 27 April 1927.

At the opening session, the President of the GSSA, the geologist Alexander Logie du Toit (1878-1948) (Figure 2), spoke as follows:

Last year the Spanish Government invited this country to send a representative to he Fourteenth Congress about to be held at Madrid, and the Union Government deputed Dr. A.

L. Hall to attend. His visit brought out the fact that very many of the members present, as well as the Executive itself, were desirous of having the opportunity of visiting and studding this remarkable country. He accordingly represented those views to the Council of the Geological Society, whence [came] the satisfactory announcement made to you tonight. . . . So far as possible the Congress meets in some particular territory, its executive being drawn from the leaders of geological thought in that country. Each excursion is arranged so as to illustrate some particular geological problem or type of mineral deposit. As it happens, South Africa is a country of really outstanding geological and mineralogical interest. It possesses problems in nearly every branch of geology that are uncommon, and, in certain instances, unrivalled or unique, while, on the economic side, it can furnish most striking object lessons. Few countries could present so excellent a claim as the venue of one of the International Congresses. As regards the advantages, which we, in his country, could expect to obtain from this meeting, they are indeed many. Too insufficiently is it realised that isolated in this country there are labouring in geological and mining teaching, survey and research, a relativity small band out of direct touch with the leaders of thought and

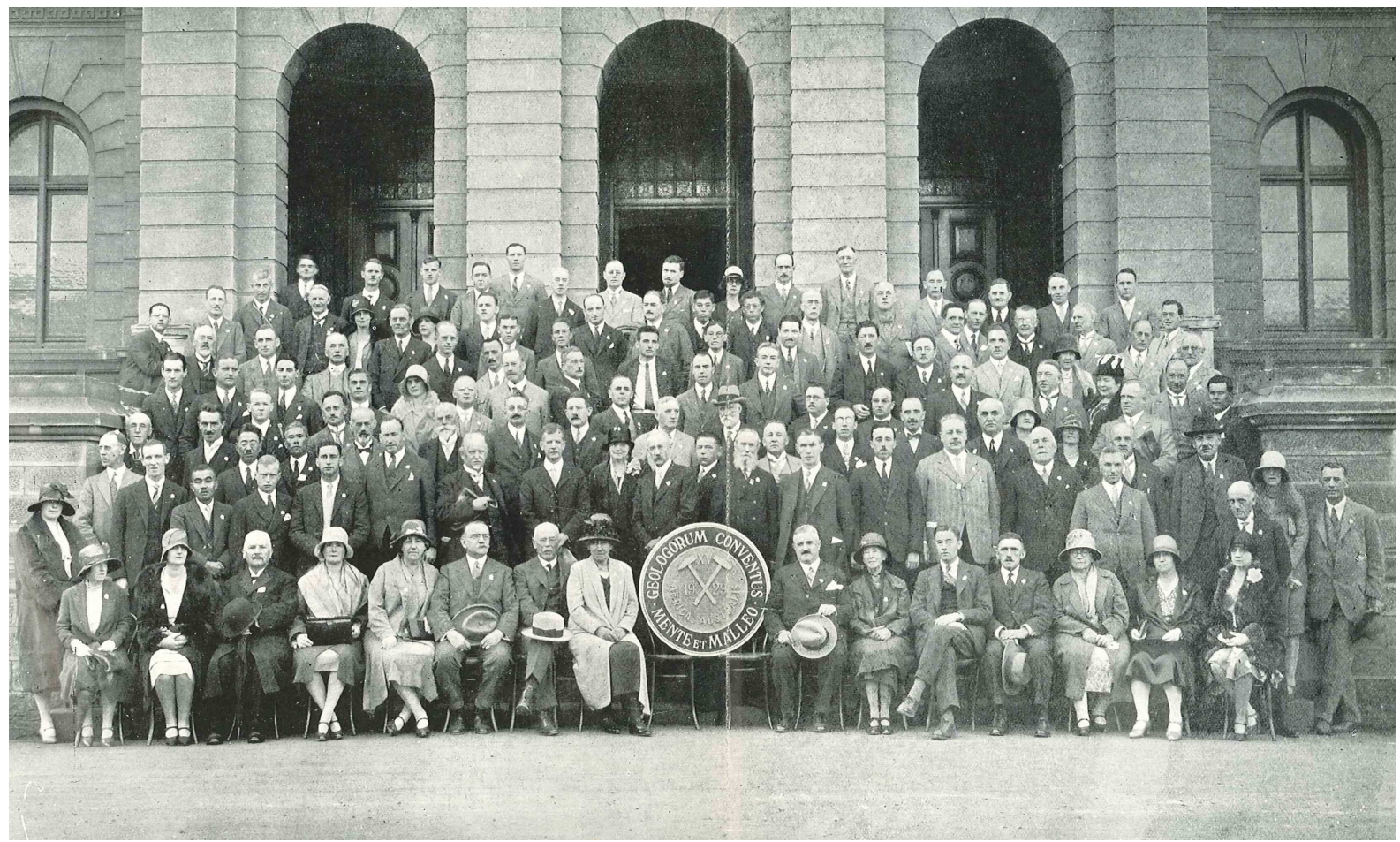

Figure 1. Some of the attendees, with the logo of the 15th IGC 

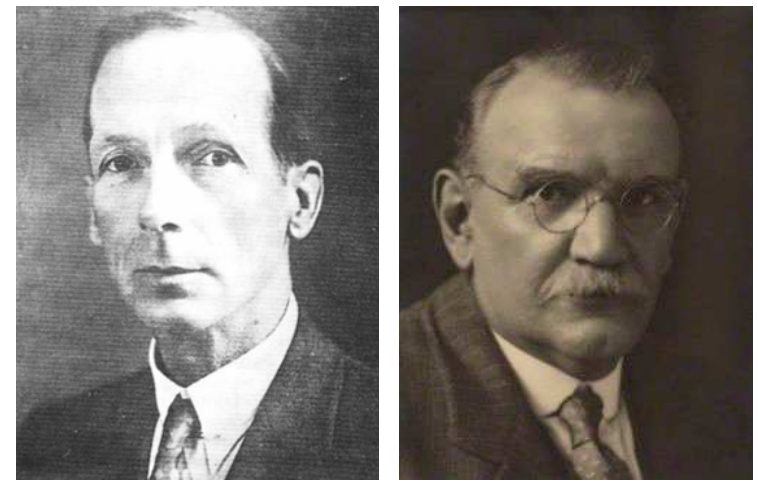

Figure 2. Left: Alexander du Toit, President of the GSA (RSDA Geological Survey); Right Arthur Lewis Hall, Secretary General of the 15th IGC (National Portrait Gallery www.npg.org.uk).

investigation elsewhere. To be able to meet these eminent specialists with an international repute to discuss our peculiar problems with them: to draw upon their extensive and varies knowledge and finally to show them in return some of our novel and, in some instances, unrivalled sections and mineral deposits, would indeed be a mutual education and lead to the advancement of geological thought the world over and in South Africa in particular (Anonymous, 1930a).

Later on, the Organization Committee was approved, under the honorary presidency of the Prime Minister of the Union of South Africa. Arthur Williams Rogers (1872-1946) (Director of the GSSA) was chosen as President. Arthur Lewis Hall (Assistant of the first Director of the GSSA, between 1916 and 1932, the year in which he retired) (Figure 3) was chosen as Secretary General and E. H. Banks, cartographer with the GSSA, as Treasurer. The first circular was distributed in July 1927. That letter gave preliminary information about the Congress, but without tackling some issues in depth, due to the fact that the organizers were engaged in negotiations with the cabinet of the Minister for Railways and Harbours, with the purpose of ensuring adequate logistics for the fieldtrips of the Congress. In February 1928 the second circular was published, giving more detail about the intended program, as well as the prices for registration. The third circular, dated September 1928, and the fourth, in February 1929, informed of the extension of the fieldtrips program, including a long journey, after the Congress to Northern Rhodesia (Anonymous, 1930a).

\section{List of Registered Delegations}

A total of fifty-five international delegations were registered (see Table 1). According to what can be gathered from a book of papers of the Congress (Compte Rendu of the XV Session, South Africa, 1929, Volume 1), a total of 573 people, businesses and associations registered, of which more than half (specifically 296) actually attended (see Table 1) (Anonymous, 1930a; Hall, 1930).

The language for the presentation and publication of works was not specified but most of the 79 presented communications were in English (38\%). There was also German (24\%), French (19\%), Italian $(15 \%)$ and Spanish (4\%) (Anonymous, 1930b). The Congress sessions were held in the Extra Mural Buildings in Vermeulen Street, in the centre of Pretoria. The opening Session was on Monday 29 July at 11 a.m. The General Assembly was held on Friday 2 August, and the
Table 1. List of Delegations

\begin{tabular}{|c|c|c|c|c|c|}
\hline Country & $\begin{array}{l}\text { Registra- } \\
\text { tions }\end{array}$ & $\begin{array}{l}\text { Atten- } \\
\text { dees }\end{array}$ & Country & $\begin{array}{l}\text { Registra- } \\
\text { tions }\end{array}$ & $\begin{array}{r}\text { Atten- } \\
\text { dees }\end{array}$ \\
\hline Aegean Islands & 1 & 0 & Korea & 1 & 1 \\
\hline Angola & 2 & 2 & Madagascar & 4 & 4 \\
\hline Argentine & 3 & 0 & Manchuria & 4 & 1 \\
\hline Australia & 5 & 3 & Morocco & 2 & 1 \\
\hline Austria & 5 & 3 & New Zealand & 4 & 2 \\
\hline Bechuanaland & 1 & 1 & Nigeria & 1 & 1 \\
\hline Belgian & 10 & 4 & Northern & 8 & 8 \\
\hline Congo & & & Rhodesia & & \\
\hline Belgium & 19 & 2 & Norway & 2 & 1 \\
\hline Bolivia & 1 & 1 & Nyasaland & 1 & 1 \\
\hline Canada & 7 & 6 & Peru & 1 & 0 \\
\hline China & 2 & 1 & Poland & 8 & 5 \\
\hline Czechoslovakia & 11 & 2 & Portugal & 2 & 0 \\
\hline Denmark & 1 & 0 & $\begin{array}{l}\text { Portuguese East } \\
\text { Africa }\end{array}$ & 2 & 2 \\
\hline Dutch East Indies & 4 & 0 & Romania & 8 & 2 \\
\hline Egypt & 3 & 2 & Scotland & 4 & 2 \\
\hline England and Wales & 41 & 32 & Sierra Leone & 2 & 2 \\
\hline France & 27 & 5 & $\begin{array}{l}\text { Southern } \\
\text { Rhodesia }\end{array}$ & 10 & 10 \\
\hline $\begin{array}{l}\text { French Equatorial } \\
\text { Africa }\end{array}$ & 2 & 1 & Spain & 18 & 2 \\
\hline French Indo-China & 2 & 1 & Sudan & 2 & 1 \\
\hline French West Africa & 2 & 2 & Sweden & 5 & 2 \\
\hline Germany & 77 & 36 & Switzerland & 14 & 3 \\
\hline Gold Coast & 3 & 3 & $\begin{array}{l}\text { Tanganyka } \\
\text { Territory }\end{array}$ & 3 & 3 \\
\hline Greece & 3 & 1 & Tunis & 1 & 1 \\
\hline Holland & 4 & 2 & Uganda & 2 & 1 \\
\hline Hungary & 10 & 3 & $\begin{array}{l}\text { Union of South } \\
\text { Africa }\end{array}$ & 117 & 84 \\
\hline India & 1 & 0 & USA & 59 & 35 \\
\hline Italy & 21 & 4 & USSR & 13 & 2 \\
\hline Japan & 7 & 2 & Total & 573 & 296 \\
\hline
\end{tabular}

closing session was on Wednesday 7 August (see Figure 5). There were fieldtrips and sightseeing before, during and after the Congress, as well as diverse receptions and cultural activities.

\section{Field Trips}

In accordance with the practice at previous IGC meetings, each fieldtrip was coordinated by a specialist in the subject, and a Guide Book was prepared for each of the twenty-two trips, as well as an introductory text under the title The Geological Structure of the Union, prepared by Arthur Williams Rogers (1872-1946). The fieldtrips treated two issues: on the one hand, the geology of areas selected for their scientific interest, and on the other hand, mines, and mineral deposits (see Figure 3).

The fieldtrips, designed to show interesting geological information and localities, were as follows:

a) A1 (Chapman's Peak, coordinated by Andrew Young) and A2 (Table Mountain coordinated by the British army doctor, geologist and palaeontologist Sidney Henry Haughton) were dedicated to the study of Table Mountain - a plateau with magnificent views over Cape Town. It is formed from horizontal layers of Ordovician quartzitic sandstone. The basement consists of folded and altered phyllites and hornfelses (Malmesbury Shales). 


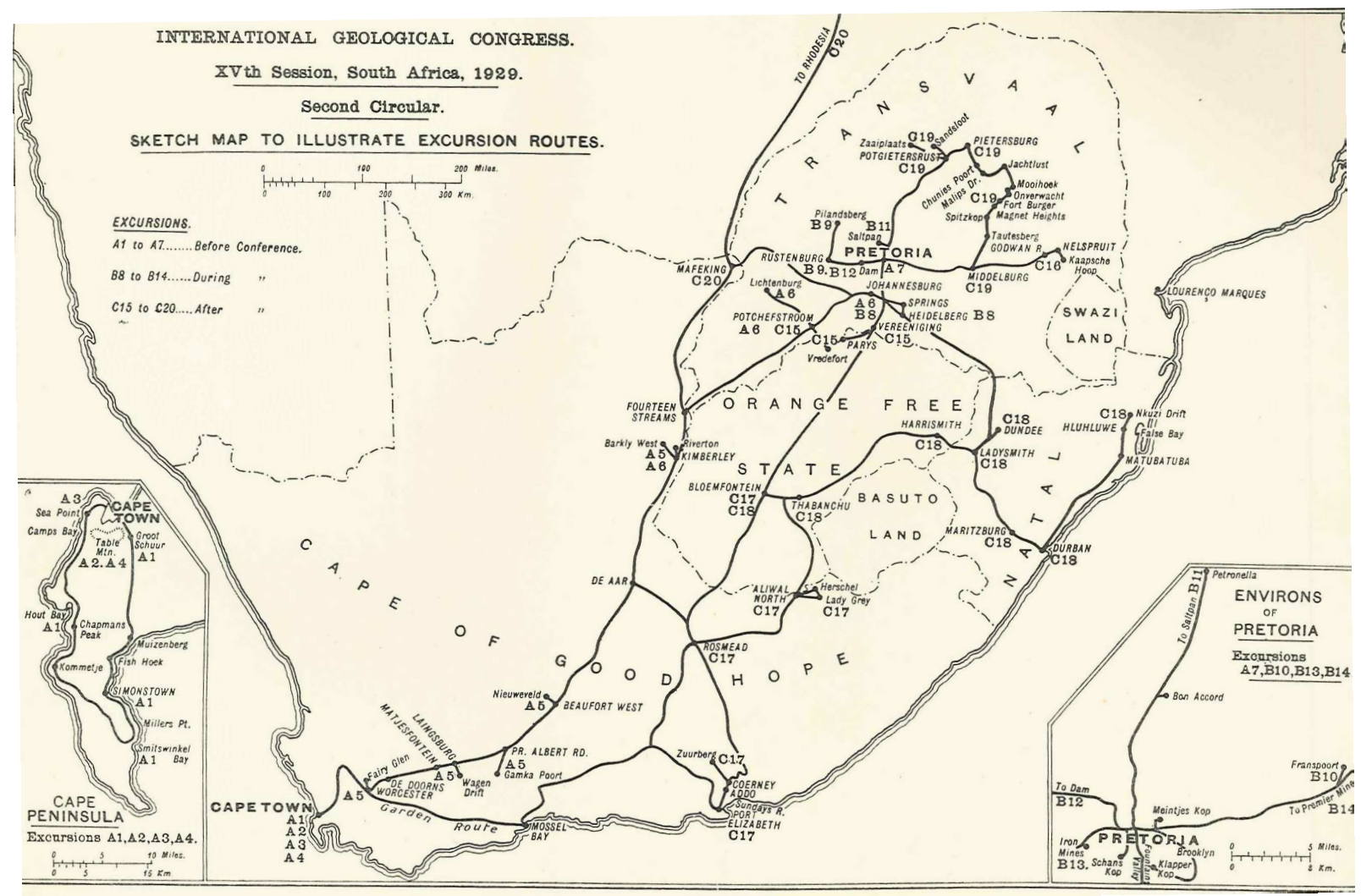

Figure 3. Map showing the routes of the fieldtrips of the 15th IGC.

b) A3 (The Seapoint Granite-Slate Contact, directed by A. R. E. Walker) centred on the recognition of the mixed rocks zone (mixed slate and granitic material) at the contact and a large xenolith of banded granite.

c) A4 (Cape Kimberley, coordinated by Sidney Henry Haughton and Alexander L. Du Toit), dedicated six days to the inspection of Table Mountain, including the hot spring of the Table Mountain Sandstone and Bokkeveld Beds, and the dolerite intrusions at the top of Nieuweveld Pass.

d) A6 (Environs of Pretoria, coordinated by Leo Jacobus Krige, 1884-?) dealt with the inspection of banded dolomites with interbedded layers of chert, the Daspoort Till, and the Ongeluk lava (an andesite with a large amygdales, up to $30 \mathrm{~cm}$ in diameter).

e) B10 (The Alkaline Rocks of Franspoort and Leewfontein, directed by Samuel James Shand, 1882-1957, see Figure 4) was dedicated

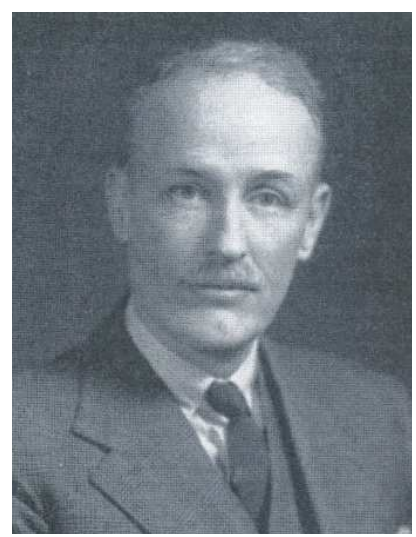

Figure 4. The Edinburgh geologist Samuel James Shand, who directed Fieldtrip B10 (American Mineralogist, 43, 1958). to the inspection of the material (which contained quite a lot of eudialyte and astrophyllite), and collecting samples of white foyaite.

f) B11 (The Pretoria Salt Pan, directed by Percy Albert Wagner, 1885-1929). The Pretoria Salt Pan, 40 km north-west of Pretoria, South Africa, is near a supposed impact crater, of circular outline, about $1,140 \mathrm{~m}$ in diameter, excavated in the red granite of the Bushveld Complex. The floor is $60 \mathrm{~m}$ below the general ground level and is underlain by at least $70 \mathrm{~m}$ of saline clay beds; a rim 15-60 m high surrounds the crater.

g) C15 (The Vredefort Granite Dome in the Northern Orange Free State and the Southern Transvaal, directed by Arthur Lewis Hall) was dedicated to inspecting the geology of the Vredefort Granite, with overthrusting metamorphism, crush phenomena, and contrasts between the central (older) granite and the younger alkali granites, etc.

h) C17 (Port Elizabeth, directed by Sidney Henry Haughton) was useful to gather fossil samples of the Cretaceous and Tertiary beds and a new type was even discovered: a Lepidotid fish. It was an extinct genus of the Actinopterygii (fin rays), which lived from the late Triassic to the early Cretaceous in the oceans and fresh waters worldwide.

i) C18 (Durban-Zululand, coordinated by Alexander L. du Toit and E. C. N. van Hoepen, Figure 5) was largely conducted on board a train from Pretoria, which stopped at points of geological interest and and the excursion leaders explained the most important features at each stop. It emphasized the inspection of the Munyuana Beds (Turonian), which have been opened up in a railway cutting.

j) The rest of the fieldtrips were chiefly dedicated to the examination and description of mineral deposits. 


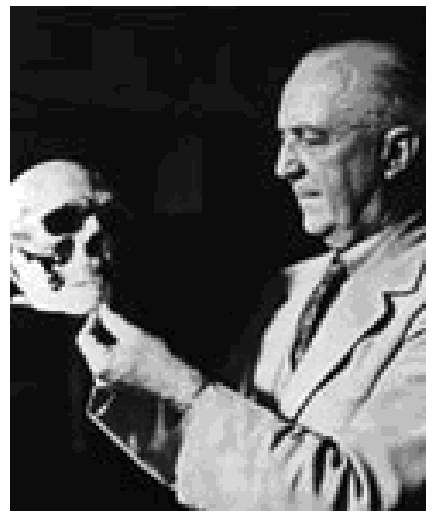

Figure 5. E. C. N. Van Hoepen who with Alexander L. Du Toit directed Excursion C18 (History National Museum, Bloemfontein).

\section{Issues for Debate}

The issues treated at the 15th IGC were structured in seven thematic sessions:
I. Magmatic differentiation (8 papers)
II. Pre-Pleistocene glaciation (7 papers)
III. The Karroo System (stratigraphy, paleontology and world distribution (15 papers)
IV. The genesis of petroleum (4 papers)
$\mathrm{V}$. The geological work of microorganisms (2 papers)
VI. Rift valleys (7 papers)
VII. General (36 papers).

From the analysis of the works presented it can be seen that there were various matters of special interest that were treated at the Congress, notably: (a) the elaboration of the African Geological Map; (b) the development of the geophysical techniques; (c) the genesis of mineral deposits, etc. Continental Drift was an issue that was also to the fore. The session dedicated to the geological work of microorganisms was something of an 'odd man out'.

\section{The African Geological Map}

In the first geological maps of the world, such as The Geological Structure of the Globe (1855; first manuscript version exhibited 1843) of Ami Boué (1794-1881), Africa was only represented in its North part (with a little of the West Coast and of South Africa) with any accuracy, due to the fact that only a few areas of the continent had been studied, particularly with the geological map of northern Algeria (1847), (scale 1:2,000,000) by Emilean Jean Renou (1815-1902). Boué coloured in the central areas of the continent, but largely on the basis of analogy and guesswork.

With the purpose of completing the knowledge of the continent, the Commission for the Geological Map of Africa was established at the Brussels IGC (1922), thanks chiefly to the efforts made by Emmanuel de Margerie (1862-1953) and John Evans (1857-1939). This Commission presented its conclusions at the Madrid IGC (1926), by which time all the African regions where English was spoken had geological maps on a scale of 1:1,000,000 (Arnaud, 1927). From 1924, the Belgian Congo had a map of 1:2,000,000, the work of Paul Fourmarier (1877-1970). The Germans had compiled maps 1:6,000,000 for South West Africa and the French had also been publishing some maps, such as the geological map of Algeria (1900), on a scale $1: 800,000$, or the Dahomey map (1908), on a scale 1:1,250,000, both by Henry Hubert (1879-1941). The advances in these fields were to be communicated at the Pretoria IGC (Brandao, 2008).

Finally, in Pretoria there was a presentation of the geological map of Tunisia, 1,500,000 by Marcel Solignac, and the geological map of Angola on a scale of 1:5,000,000, compiled by the Portuguese geologists Fernando Mouta and Alexandro Borges. Subsequently in 1933, at the Washington IGC, Mouta and Henrique O'Donnell presented a work with greater detail, on a scale 1:2,000,000; and in the same scientific session Giusseppe Stefanini (1882-1938), an Italian palaeontologist who distinguished himself for his contributions to the geology of Libya, Ethiopia and Somalia (by then Italian colonies), communicated his work Successione ed Etta della Serie di Lugh nella Somalia Italiana. The vast amount of material gathered during the numerous scientific expeditions in which he participated allowed him to produce the Geological Map of Somalia, Ethiopia and Eritrea (Gardner, 1940).

The Geological Map of Africa, 1:8,000,000, by A. Katchevsky, with the collaboration of Bourcart (1891-1965), was published definitively in 1933 by the Institut Cartographique of Paris.

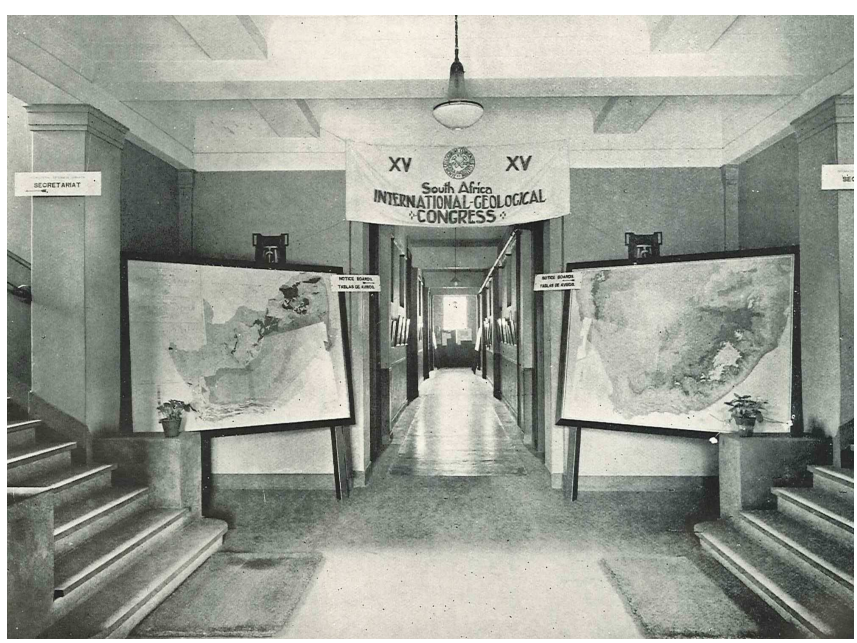

Figure 6. Geological maps of South Africa displayed at the entrance to the sessions rooms of the 15th IGC. Attendees were able to purchase the Geological Map of the Union of South Africa, scale 1:1,000,000, for $£ 1.50$.

\section{Geophysical methods applied to mining exploration}

Robert Were Fox (1789-1877) was the first to apply electrical methods in mining exploration, thanks to the observation of the natural electric potentials associated with the sub-volcanic copper deposits in Cornwall. At the end of the nineteenth century, Carl Barus (18651935) made polarizing measurements in investigations of the gold and silver mines of Comstock Lode in Nevada. In the same way, Fred H. Brown, and after him Alfred Williams (1871-1945) and Leo Daft (1843-1922), made the firsts attempts to determine the relationship between terrains associated with gold deposits (Molina Padrón, 2006). And in 1901 they founded The Electrical Ore Finding Company Ltd. (Vernon, 2011). In 1912, the professor of the Paris Mining School, Conrad Schlumberger (1878-1936), proposed the idea of mining exploration for metallic deposits through the use of the induced polarization method and the measurements of the artificial generated 
potentials. Between 1923, with his brother Marcel (1884-1953), he began studies for different mining and oil companies, creating resistivity maps. Their success led them to found the Société de Prospection Électrique (1926) and in 1927 they initiated the world's first electric log. At the same time as the Schlumberger brothers, Wenner developed such work at the U. S. Bureau of Standards, inventing the arrangement of electrodes for determining resistivities that carries his name.

Between 1914 and 1915 there appeared the first use of a magnetometer in mining exploration. This was the Adolf Schmidt (1860-1944) variometer, which measures the vertical variations of the magnetic field. However, between 1915 and 1916 gravimetric methods were being used (specifically the torsion pendulum of the Baron Loránd Eötvös de Vásárosnamény (1848-1919) in the study of the Egbell oil field, in Slovakia. A little later, using this method, Schweidar identified a diapir in Hnigsen (Germany), a structure that was confirmed by drilling (Sah, 2003). In 1917, Harry W. Conklin patented the electromagnetic method of high frequency (EM) for mining exploration. Lastly, the seismic methods began to be applied in oil exploration during the 1920 s — seismic refraction being employed in Iran (1920) and Mexico (1923) and seismic reflection in the Maud oil field of Oklahoma (1927).

At the 14th IGC in Madrid (1926), José García Siñeriz (18861974; chosen during the 15th IGC as President of the Geophysics Commission (Spanish Geological Survey, IGME) (see Figure 7) had presented, along with other mining engineers, a communication on the geophysical studies in the potassic basin of Catalonia (Spain). At

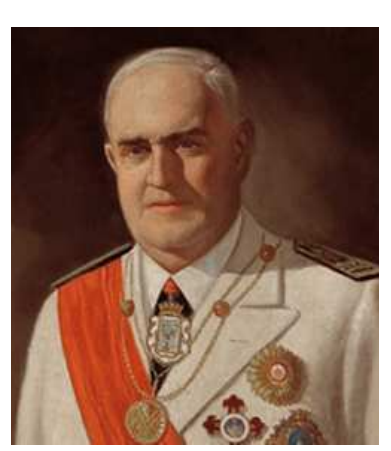

Figure 7. José García Siñeriz that meeting he was commissioned to prepare a study on Geophysical Methods of Exploration, to be presented in the Pretoria Congress (Anonymous, 1947). In 1928, Siñeriz published a book with this title, in which the formulae and instruments used in this kind of work were described (which up till then had remained confidential because of commercial considerations). The book's importance was mentioned at the opening of the 15 th IGC by F. V. Beyers, the South African Minister of Mining and Industry (Anonymous, 1929). During the course of the Congress, García Siñeriz presented three works on geophysical investigations undertaken in Spain: in Alcala de Henares (Madrid); the coal mines of Villanueva y Minas (Córdoba); and in the fault zone of the Guadalquivir valley. Commissions to study the works of the next congress were established on 7 August 1929, and García Siñeriz was chosen as President of the Geophysics Commission.

As regards geophysics, gravimetric and seismic work in Central Asia was also presented in the General Section of the Congress by the Russian paleontologist Dimitrii Mushketov (1882-1938) (Soloviev, 2007). Mushketov was executed during a period of prosecutions and political reprisals of Stalin, between 1936 and 1939. Other works on geophysics were presented by the mining engineer Paul Charrin, dealing with the application of the electrical methods (spontaneous polarization) in the study of copper mines of the Congo, as well as by the German H. Reich from Berlin: 'Uber die physicalischen eigenschaften geologischer Körper' ('On the physical properties of geological bodies').

\section{Magmatic differentiation}

Between the end of the nineteenth century and the beginning of the twentieth century, the concept of magmatic differentiation was developed and its basic mechanisms described, thanks to authors like Heinrich Rosenbuch (1836-1914), Jethro Teall (1820-1880), John Wesley Judd (1840-1916), Helge Mattias Bäckström (1865-1932), Alfred Harker (1859-1939), George Ferdinand Becker (1847-1919), Franz Y. Loewison-Lessing (1861-1939), Joseph Iddings (18571920), Johan H. L. Vogt (1858-1932), et al. (Young, 2002; Davis, 2003).

In his book Igneous Rocks and their Origin (1914) the Harvard professor of geology, Reginald Aldworth Daly (1871-1957), defended the idea of a single 'mother' magma, from which all igneous rocks derived. In his long article 'The Later Stages of the Evolution of the Igneous Rocks' (1915), Norman Levi Bowen (1887-1956), a disciple of Daly, in signalled the idea that basalt was the primary magma. Bowen sustained his ideas on the primary magma in his book The Evolution of Igneous Rocks (1928). In this work, his best-known, he developed the concept of fractional crystallization and established his famous 'reaction series' (Yoder 1992). In the 1920s serious doubts began to emerge about differentiation from a unique magma. This was founded on the great variety of igneous rocks and on other circumstances also, such as, for instance, the fact that there are not many basalts in the Andean zone. In 1923, the Swiss petrologist Paul Niggli (1888-1953) and P. J. Berger published, Gesteinsund Mineralprovizen, which analyzed the associations of minerals and rocks in different regions (magmatic provinces), and argued over the processes of magmatic differentiation. It also established the first catalogue of different kinds of magma, from which the different rocks were subsequently formed by differentiation. In this way, three magmatic series could be defined: calco-alkaline, potassic and sodic. (However, the term 'petrographic province' had been used by previous authors such as Judd (1886) and Lacroix (1902), among others.)

Among the participants in the session was Paul Niggli, who presented a paper Comments on the problem of Magmatic Differentiation, in which he proposed that studies of differentiation should be done assuming the existence of different petrographic provinces, with theoretical-experimental studies being undertaken to determine of the factors that control the differentiation.

The paper called attention to the correlation that some authors established at the 15th IGC between magmatic differentiation and the genesis of mineral deposits, such as the case of the Japanese Takeo Kato of the Imperial University of Tokyo in his studies on the subvolcanic deposits of $\mathrm{Au}-\mathrm{Ag}$, and the works of the Canadians Arthur Phillemon Koleman (1852-1935), Edmon S. Moore (1878-1966) and Thomas Leonard Walker (1867-1942) on the nickel deposits of Sudbury, Ontario, and the works of Ernest von Reuning in Bushveld and other South African deposits.

\section{Genesis of mineral deposits}

Given South Africa's great mining riches, it should not come as a surprise that about half the fieldtrips were orientated towards visiting, and following the technical explanations of, the mines and deposits. Concretely, the fieldtrips were the following (Anonymous, 1930a):

a) A5 (Kimberley-Johannesburg, coordinated by Alexander L. du Toit, Arthur Williams Rogers and Percy A. Wagner). This excursion visited the diamond mines of Kimberley (see Figure 9) 


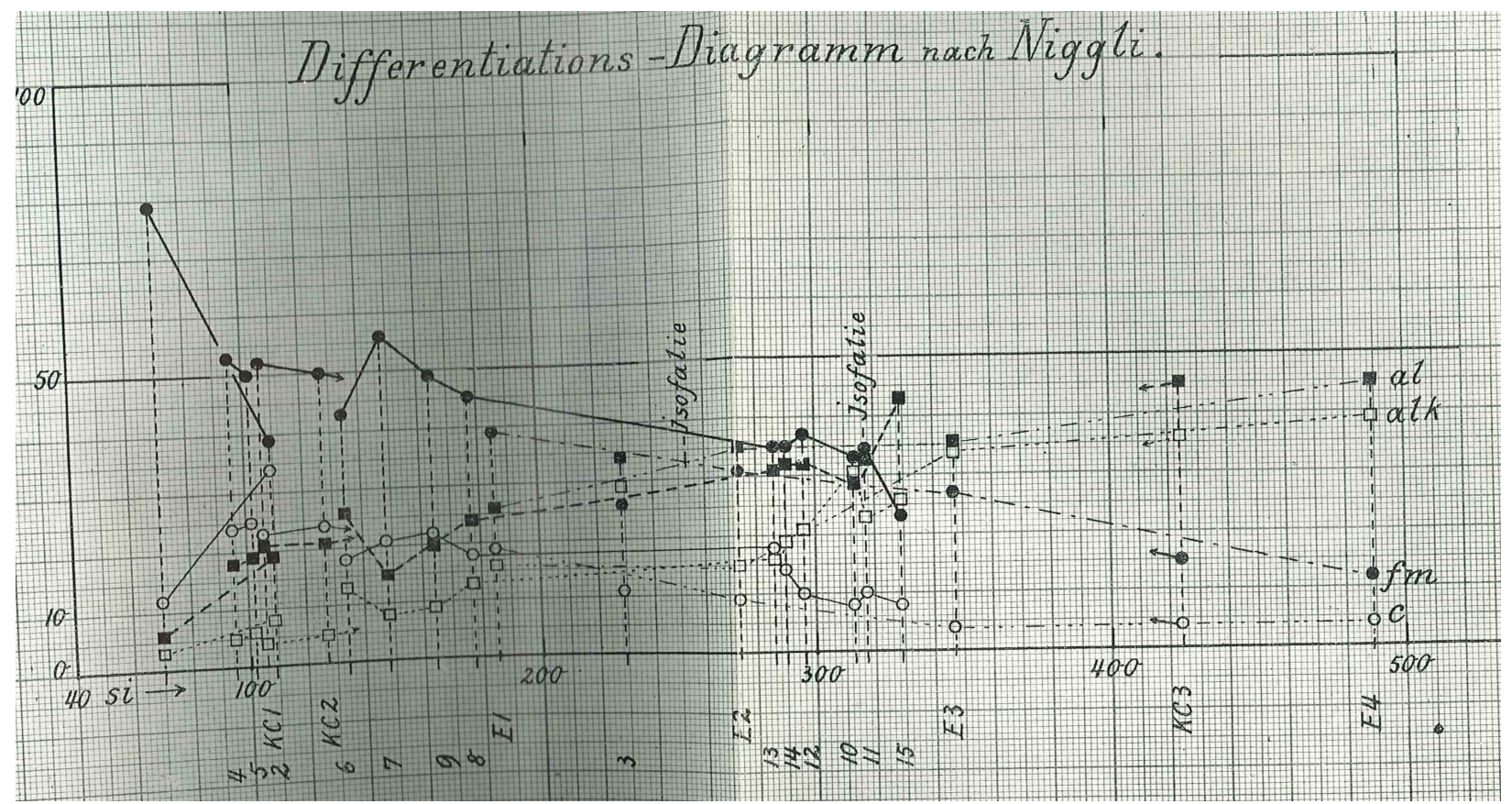

Figure 8. Niggli's diagram of magmatic differentiation of the Karroo formation in Kaokofeld (Namibia) by E. Reuning.

and the calcification processes of the kimberlites were observed. They were subdivided into two types according to petrographic observations: 'basaltic' and 'micaceous' (Wagner, 1914).

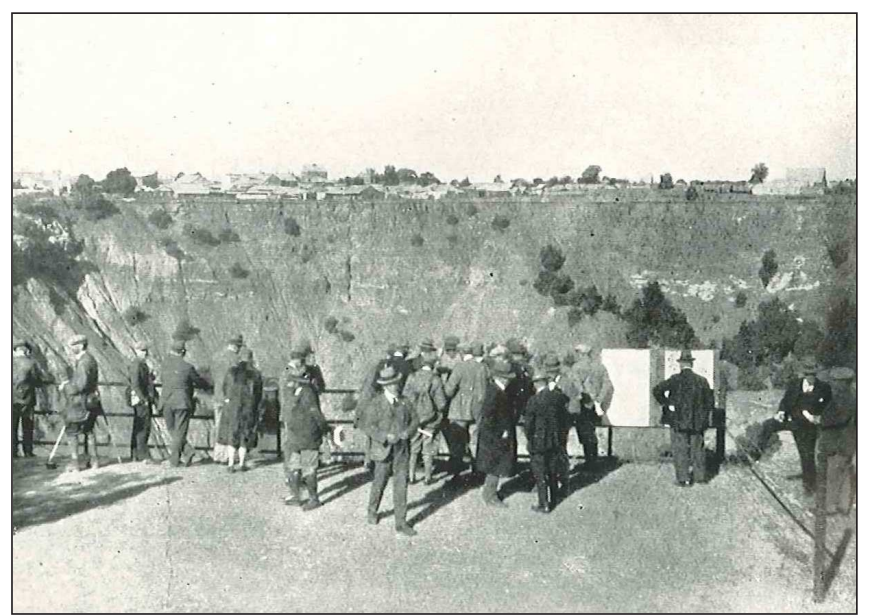

Figure 9. Visit to the diamond mines of De Beers, Kimberley.

b) B8 (Johannesburg, directed by Arthur Williams W. Rogers) lasted for three days. During the first, the geological characteristics of the Witwatersrand mining district were explained. The second day followed the road that goes through City Deep Mine up to Heidelberg, and the attendees observed some slate basset. During the third day, they travelled to the Langlaagte Estate and Gold Mining Co., where they could observe the exploitation of the auriferous conglomerates, as well as the trituration processes, mining, milling and concentration tables, where the $57 \%$ of the gold was recovered, prior to the application of the cyanide process.

c) B9 (The Rustenberg Platinum Deposits and Pilanberg, coordinated by Percy A. Wagner and Samuel James Shand) allowed the examination of the great dike of foyaite (a potassium feldspar rich syenite) at Spruitfontein. Also visited was the
Klipfontein-Kroondal platinum mine where the visitors were shown hundreds of feet of exploration where the compositional variations of the norite from the surface down to the Merensky Reef.

d) B12 (The Hartebeestpoort Dike, coordinated by Alexander L. du Toit) where the Bushveld Complex was examined from its base up to the granophyre, which included pyroxenite, chromitite and a syenite dike.

e) B13 (The Pretoria Iron Ore Deposits, under the direction of Percy A.Wagner) in which banded iron formations were visited.

f) B14 (The Premier Diamond Mine, coordinated by Percy A. Wagner). The Premier Diamond Mine, forty kilometres east of Pretoria, is a diamond field where exploitation had begun in 1902, at the end of the Second Boer War. Thomas Cullinan (later Sir Thomas, 1862-1936) had bought the lands for $£ 52,000$. The famous Cullinan Diamond was found in this mine in 1905 and is still the largest diamond found in recorded history. It weighed 3,000 carats (gross) and was presented to King Edward VII as a birthday gift, who ordered it to be to cut in 1906. The various cut diamonds presently form part of the Crown Jewels of the British monarchy.

g) C16 (The Devil's Kantoor in the Great Eastern Escarpment of the Transvaal Drakensberg, directed by Arthur Lewis Hall), where besides visiting the old workings of Barret's Berlin Gold Mine participants also inspected the New Amianthus Mine, where samples of stichtite, magnesite, talc, chromite, serpentine and dolerite were collected. New Amianthus is an asbestos mine, located on the eastern slopes of the Drakensberg, three miles north of Kaapsche Hoop.

h) $\mathrm{C} 19$ (The Bushveld Igneous Complex with special references to the Eastern Transvaal, coordinated by Arthur Lewis Hall). This excursion centred on visiting various mining localities and operations. Among others, the Zaaiplaats Tin Mine was visited. The group also visited the Potgietersrus Platinum Mines, and the altered banded ironstone formations were examined. The 
organizers chose the Shabani Mine and Nil Desperandum as the first stop, and, as with the rest of the fieldtrips, observations were mingled with explanations of the geological features of the places visited.

i) C21 (South West Africa, coordinated by Herbert Francis Frommurze and Traugott Wilhelm Gevers (1900-1991). (There is a platinum mineral, geversite, named in Gevers' memory.) There were visits to the diamond field of south of Pomona and the alkaline intrusion of Granitberg and its system of dikes, the fossils of the blankets of marine Tertiary, and the picturesque hollow rock of Schwartzkalk, limestone called the Bogenfelds. The attendees saw the concentration plant of Elizabethbutcht. They could also observe the cutting of diamonds for their export, valued at $£ 100,000$.

j) C22 (Notes on the General Geology of Northern Rhodesia, coordinated by Joseph Austen Bancroft and R. A. Pelletier). This excursion was oriented towards economic geology, being organized in such a way that important mines of the region could be visited: Bwana M'Kubwa (copper), the underground Roan Antelope Mine (copper), the N'Kana Mine (in modern Zambia), etc. (see Figure 10).

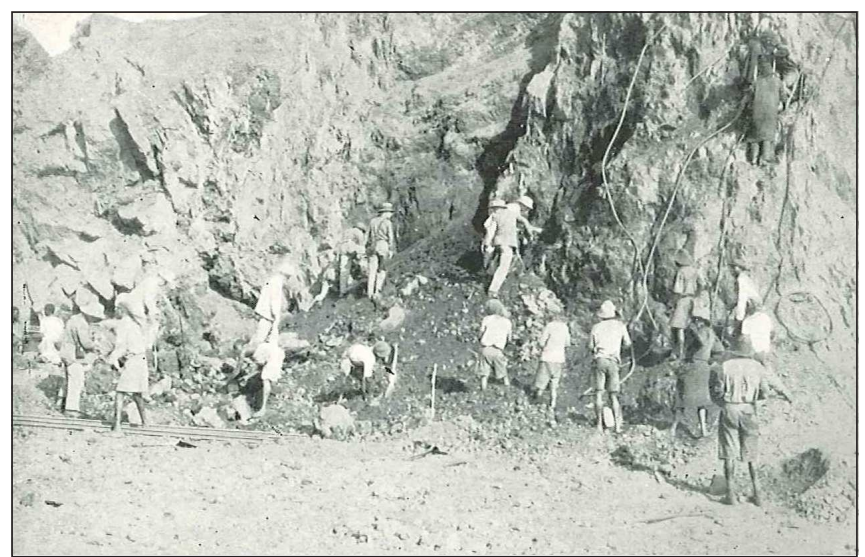

Figure 10. Visit of excursionists to the mines of Broken Hill, Rhodesia

Though it was not organized as a specific scientific session, there were several presentations of researchers directly related with the topic of the genesis of mineral deposits. For example: the Frenchman Léonce Joleaud (1880-1938) described the lead deposits of Tunisia; the Japanese Kameri Kinoshita analysed the sulphur deposits of Kuromono in Japan; the Belgian engineer Jacques Thoreau (18861973) reported his studies of the copper ores of Rhodesia, Congo, etc.

\section{Rift valleys}

The notable British explorer and geologist John Walter Gregory (1864-1932) was the first, in 1896, to describe the Great Valley of the African Rift, with its group of faults involved in the process of rifting. For Eduard Suess (1831-1914), Gregory, and others, the faults were caused by extensional forces (Bowen, 1938), though this was shortly after questioned by Karl Uhlig (1907). The British geologist Edward James Waylan (1888-1966) claimed to have seen reverse faults in the Albertine Rift. In this way, there could be faults generated by extensional forces in the Eastern Rift and by compressive forces in the Western Rift (Wayland, 1921). Howard Lecky Sikes (1881-

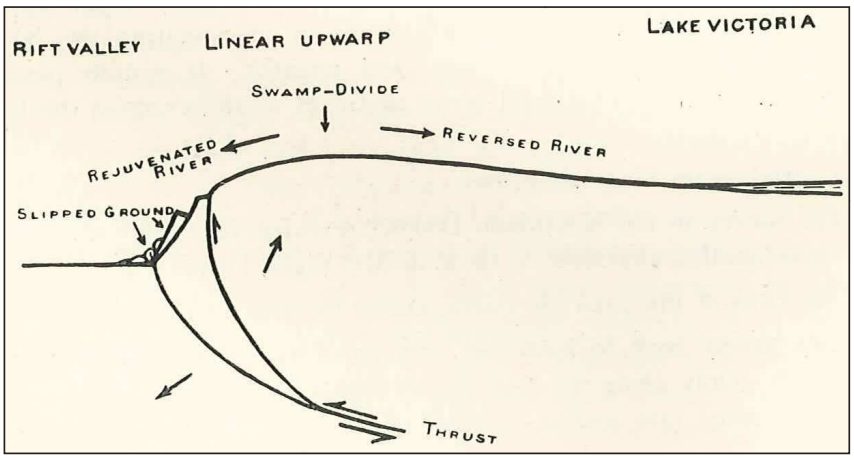

Figure 11. Wayland's scheme, for the western branch of the African rift valleys.

1943), of the Kenya Mining and Geological Survey, studying the eastern side, believed that the process is provoked by tensile stress (Sikes, 1926). During the 15th IGC, Wayland, then Director of the Geological Survey of Uganda, presented a compressional model (see Figure 11). As it might be expected, there were geologists who could not agree, During the 15th IGC, the German engineer Erich Seidl also proposed the existence of rift valleys in Central Europe.

\section{Continental drift}

The 15th IGC was held at a time when there was a topic, above all the others, that was giving rise to important controversies in the geological community: Alfred Wegener's (1880-1930) theory of the 'Continental Drift'. Years before, on 6 January 1912 to be precise, during the Annual Meeting of the Geology Union being held in the German city of Frankfurt, Wegener expounded his theory that the continents had been formerly been united, making up a single continental mass (Pangaea), that became divided in the Mesozoic and that the fragments thus formed had subsequently drifted towards their current positions (Pérez-Malváez et al., 2006). This hypothesis was supported by a series of facts: 1 . the flora and fauna at the end of the Paleozoic was quite similar in South America, southern Africa, Australia, and India. The primitive continental union was confirmed by the presence of fossils of Mesosaurus, a reptile found in the Permian of both South Africa and South America. This reptile would have been incapable of crossing the Atlantic. Similarly, the presence of a fossil fern, Glossopteris, would help to support the idea of the existence of Pangaea. 2. Wegener, also found petrographic similarities between ancient igneous rocks in Brazil and Africa. 3. The were till deposits of the late Palaeozoic in Africa, South America, Australia and India indicating that there were formerly glaciers in regions in which now there are not, yet a great part of this material (till) can be found today away from the Pole. For Wegener, they would have formed a glacier shield around the South Pole.

The reaction to his hypothesis was mostly negative. To the limited success obtained by Wegener was added his participation in a new expedition to Greenland and the beginning of World War I. That is why, for several years, he could not respond to the contrary opinions against his theory. In those years there were other two models that were successful among the international geological community. The first (contractionism) considered that the Earth had been periodically contracting since its origin, with the result that the ocean floor and the continents interchanged had themselves throughout the history of the planet. According to the second (permanentism) after an original contraction of the continental material and of the bottom of the ocean, 
according to their densities, both remained essentially the same. As a consequence, the hypothesis of the continental drift turned out to be radical and new, from the perspective of the contractionist and permanentist models. It was in 1915 when The Origin of Continents and Oceans was published, Wegener summarised his theory in less than ninety pages. After the War, he was appointed Director of the Navy's Weather Department, but dedicated himself to defending his theory, publishing two new enlarged editions of his book in 1920 and 1924. It was then that the polemics broke out. The opinions were polarized in a radical way among his defenders (mainly researchers of the Southern Hemisphere) and his detractors (geologists of the USA and Western Europe) (Marvin, 1985). At the 13th IGC in Brussels (1922), the Swiss Emile Argand (1879-1940) presented a work, Tectonique de l'Asie (published in 1924), in which he proposed the evolution of the crust in mobilist terms, according to the Wegenerian hypothesis. Argand contributed the orogeny hypothesis to Wegener's theory: there were cases of a drifting continent colliding with another one (Foreland) which ended with the sediments of the adjoining geosynclinals being 'pleated' and riding these and the Backland over the Foreland, as could have happened in the formation of the Himalayan mountains and also the Alps (Meléndez and Fuster, 1975). However, Harold Jeffreys (1891-1989) in The Earth (1924) objected that there was no force within the Earth sufficient to move continents.

The theory of the Continental Drift was largely rejected at the famous meeting of the American Association of Petroleum Geologists (New York, 1926). Wegener ideas only had the support of the organizer of the event, the Dutch mining engineer Willem Waterschoot van der Gracht (1873-1943), and was opposed by the United States scientific community, particularly Yale's geology professor Chester Longwell (1887-1975), the palaeontologist Charles Schuchert (1858-1942), the geologist and engineer Bailey Willis (1857-1949), the specialist in geodesy William Bowie (1742-1840), and the geologist Thomas Chrowder Chamberlain (1843-1928) (García Cruz, 2003).

This last author maintained that the hypothesis of Wegener was, in general, of the type of hypothesis weak argued (Tarbuck and Lutgens, 2007). At the 14th IGC in Madrid (1926) only the Norwegian Olaf Holtedahl (1885-1975) when presenting his work on the 'Tectonic of the Arctic Regions' dealt with this issue (Ayala et al., 2005). The theories of Wegener were marginalized.

In spite of this, there was an important event that turned the continental drift again into a scientific issue of primary significance. Arthur Holmes (1890-1965), in 1927 and then in 1929, proposed that convective currents within the Earth could be responsible of the break-up and movement of the continental masses (Oldroyd, 2011). Partly for that reason, interest in the theory of Wegener increased during the celebration of the 15th IGC of South Africa, perhaps due to the influence of one of its most important participants, Alexander Du Toit, who published his observations on the similarities between western Africa and eastern South America in 1927 (Du Toit and Reed, 1927, which work was quoted by Wegener in the last edition of his work. Even so, a year later, Schuchert opined that: "orthodox geology can harmonize all the exposed data in the book of du Toit" (Schuchert, 1928). As du Toit would write: "[a] hypothesis that can explain certain facts can be wrong; one that can not do it, will hardly be right" (Du Toit, 1929).

The South African mining engineer Alexander Logie du Toit (1878-1948) was contracted in 1920 by the Department of Irrigation as hydrogeologist, and in 1927 he became chief consulting geologist of De Beers Consolidated Mines, a position that he held until his retirement in 1941. These jobs allowed him to become an expert in the geology of South Africa. Years earlier, in 1923, he had received a subsidy of Washington's Carnegie Institution to travel to the eastern parts of South America and study the geology of Argentina, Paraguay and Brazil. As he wrote in his last book, Our Wandering Continents (1937), the reason for such journey was the validation of his theories about the correlations between the geology of South America and Africa, in order to defend the hypothesis of Wegener that was founded, among other things, on the way in which the forms of the two continents across the Atlantic ocean seem to 'fit'. The structures and geologic formations of other continents could at the same time be correlated, which is why it is useful to reconstruct their initial positions. Wegener also took into consideration the similarity of the fossil fauna of the northern continents and certain geological formations. The explanation that palaeontologists used to give to account for these similarities were founded on the theory of land bridges or 'isthmian links' (strips of land that were supposedly above the sea at certain times and that had allowed the passage of a great number of species from one continent to the other) (see Krill 2011). Especially striking was the presence in South America and Africa of PermianCarboniferous organisms (360-250 millions of years) that had apparently undergone a similar evolution (Cingolani, 2008). As we have already indicated, Wegener had particularly emphasized the distribution of the Glossopteris flora and the reptile family Mesosauridae.

Among Wegener's opponents was the Italian geologist Michele Gortani (1883-1966), who in an article published in the Giornali di geologia (1928), a publication edited by him and afterwards reviewed in the Geological Magazine (1930), claimed that: "Continental drift in Wegener's sense does not seem to correspond with the facts". In Pretoria he presented a paper entitled 'Deriva dei continenti e periodo glaciali', in which he maintained that according to

Huntington, Scott, etc., the glaciations on a continental scale can be caused only by variations of the Sun's activity, although, the authors of the continental drift theories insist more and more that we must look for the main cause of changes of weather in the Earth in the displacement of the continental masses, with or without the changes in Earth's climates. But neither Wegener's and Köppen's hypothesis, nor Gutenberg's Fliesstheorie, nor Staub's Bewegungsmechanismus der Erde can explain the Pleistocene glaciation, especially on account of its manifestation in all the continents together with its great interglacial fluctuations. On the other hand, we cannot find in this hypothesis the main explanation for Pre-Quaternary glacial periods, due to the fact that (1) till of the same period have been found near the poles as well as away from them, (2) no fact proves that PreQuaternary glaciations were essentially different from the Pleistocene glaciations, (3) it would not be reasonable to assume completely different causes for very similar phenomena, and finally, (4) it is logic to think that the climatic fluctuations like the ones on the quaternary have had place in the history previous to the history of the Earth. The continental rift (which I only accept with prudence and in the same sense that Staub does) it is no more that one of the reasons that together with the cosmic causes, can influence in the modification of the climates of the Earth.

He added that "continental drift, with its orographic and geographical effects, should be considered as the best theory to 
explain the great invasions of ice, though these cannot be explained in their scope and in general in their character, without having to fall back, as a determinant cause, to the variations of the Sun", pointing in a footnote: "The recent work of Leo Jacobus Krige on the magmatic cycles, continental drift and ices ages (Proc. Geol. Soc. South Africa, 1929) that I have known after sending my paper to the General Secretary of the Government does not invalidate the conclusions that I propose. The explanation of the glacial age does not seem sustainable for several reasons: 1. The theory of the magmatic cycles does not correspond to the data of the geologic history; 2. An increase in evaporation depends on the heat of the Earth, meaning that a centrifugal flux of heat would have different effects from an increase of evaporation caused by the augmentation of the solar radiation, from an outside source".

It seems that people against the theory of the continental drift were beginning to admit it as a possibility from the time of the 15 th IGC, perhaps in part because of the interventions of du Toit, who presented two works: 'A brief review of the Dwyka glaciation' and 'A short review of the Karroo fossil flora'.

In the first of these works, du Toit, after studying the glacial deposits of South Africa and considering the ones in Madagascar, Brazil, Uruguay and Argentina, with others of Australia, Tasmania, etc., reached the conclusion that all of them had a common history. The hypothesis of continental drift from Gondwana, situated in the Southern hemisphere, was strongly backed by the geological evidence, though he differed from Wegener on the disposition of the poles through the geological eras. The climatic aspect had been discussed by Köppen and Wegener as well as Brooks, though for du Toit, before applying the climatic principles it would be necessary to obtain a clearer picture of the distribution of the Earth and oceans and of the position of the South Pole in relation to the various continental masses. In the second work, du Toit proposed a continental reconstruction at the end of the Palaeozoic, on the basis of the distribution of the fauna (Figure 12).

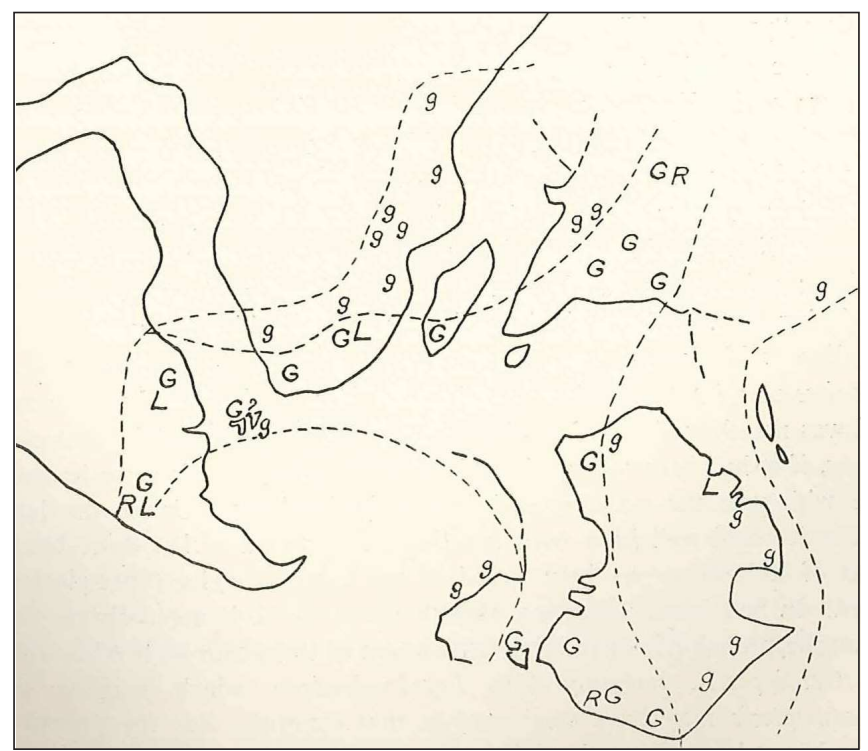

Figure 12. Proposal of Alexander du Toit at the 15th ICG on the continental positions during the Permian-Carboniferous ( $g=$ Gangamopteris, $G=$ Glossopteris, $L=$ Lepidodrendon, $R=$ Rhacopteris).
After the 15th IGC, in his book of 1937, previously quoted, du Toit formulated the hypothesis that there were two original supercontinents separated by the Tethys Ocean: one to the North (Laurasia) and other to the South (Gondwana). In addition, he suggested that the coupling of the continents could not have been on the present coast lines, but along the lines of the continental shelf, because in that way a more perfect match between the margins of the continents could be found, a hypothesis subsequently confirmed by Edward Bullard during the 1960s. One of du Toit's most significant contributions was the regrouping of Gondwana based on his knowledge of the geology of the southern continents, using the idea of a major geosyncline in the Palaeozoic, which he named the 'Geosyncline of Samfrau' (an acronym of South America, Africa and Australia), which affected the Southern Hemisphere, the south of Africa and eastern Australia.

\section{The Karroo Formation}

'Karroo' in the Hottentot language means 'dry'. The Karroo is a semi-desert plateau located the southern part of South Africa with an area of more than 400,000 square kilometres. It was explored by the German geologist Anton August Heinrich Lichtenstein (1753-1816) in the period between 1803 and 1806. After the discovery of gold in the Transvaal, there was a new impulse to the study of the geology of the region.

Jean Lombard who participated in the session dedicated to the Karroo system presenting a paper entitled: Sur une transformation metasomatique particulière du grés superieurs du bassin du Congo (Formations synchroniques du Karroo). It was published years later with Raymond Furon (1898-1986), when they were General Editors of the Geological Map of Africa, the text Explanatory Note: Geological Map of Africa (1:5,000.000). Here they described the Karroo formation in the following terms:

In southern equatorial Africa and Madagascar, Hercynian movements were followed by a major glacial period as indicated by tillites. Continental sediments with plants and reptiles continued to be deposited during the late Carboniferous, Permian and Trias. These formations were covered by basalt flows. In South Africa the Karroo attains 7,000 meters. (23,000 ft). The classical succession comprises: (a) Upper Carboniferous: Dwyka formations with tillites and Lepidodendron and Gangamopteris shales; (b) Lower Permian: Ecca formation with coal beds and a flora of Gangamopteris and Glossopteris containing European elements (Sigillaria and Bothrodendron); (c) Upper PermianLower Trias: Beaufort beds with sandstones containing a classical fauna of reptiles, amphibians and fish; (d) Upper Trias: Stormberg beds containing the last Glossopteris, Thinnfeldia and Taeniopteris and dinosaurs. The series terminates with 1,000 meters. to 2,000 meters (3,000 to 6,500 ft) of basalt flows of uncertain age. This important continental sequence is known more or less in its entirety throughout South-equatorial Africa and Madagascar. The Madagascar Karroo continues into the Bajocian-Bathonian (Furon and Lombard, 1964).

The series of non-marine layers, at the end of the Paleozoic and beginning of the Mesozoic, known as the Karroo System in South Africa, extended through a good part of Africa. So we find that the works of the French geologist Henri-Michel Besairie (1898-1978) 
on Madagascar, of the British geologist Frank Dixey (1892-1982) on the territories situated on and up the northern part of the Zambezi River, the Portuguese geologists Fernando Mouta and Alexander Borges on Angola (later on they were to work in Mozambique and the Lake Nyassa region, etc.), the Australian Edmund Oswald Teale (1874-1971) on Tanganyika, the Italian Guiseppe Stefanini (18821936) on Somalia, Frederic Philip Mennell (1880-1966), on the eastern and central Africa, etc., were presented at the 15th IGC.

Though the study centred in Africa, geologists also searched for correlations with other continents. The Australian Arthur Bache Walkom (1889-1976), compared the flora of Australia with the South African floras and, as mentioned, Alexander du Toit did the same with all the continents of the Southern hemisphere, relating different equivalent formations of approximately Triassic age:

the Cave and Bushveld sandstone of the Union, Forest sandstone of Rhodesia, Lubilache of the Congo, Adigrat beds of Abyssinia, Botucatú sandstone of Brazil, Uppermost Paganzo of Argentina and Parsora of India.

Besides the studies on the fossil fauna of the Karroo by du Toit, we have the study of Sidney Henry Haughton on the reptiles. In some way, knowledge of the Karroo and equivalent fields on both sides of the Atlantic contributed to support the theory of Wegener. So, for

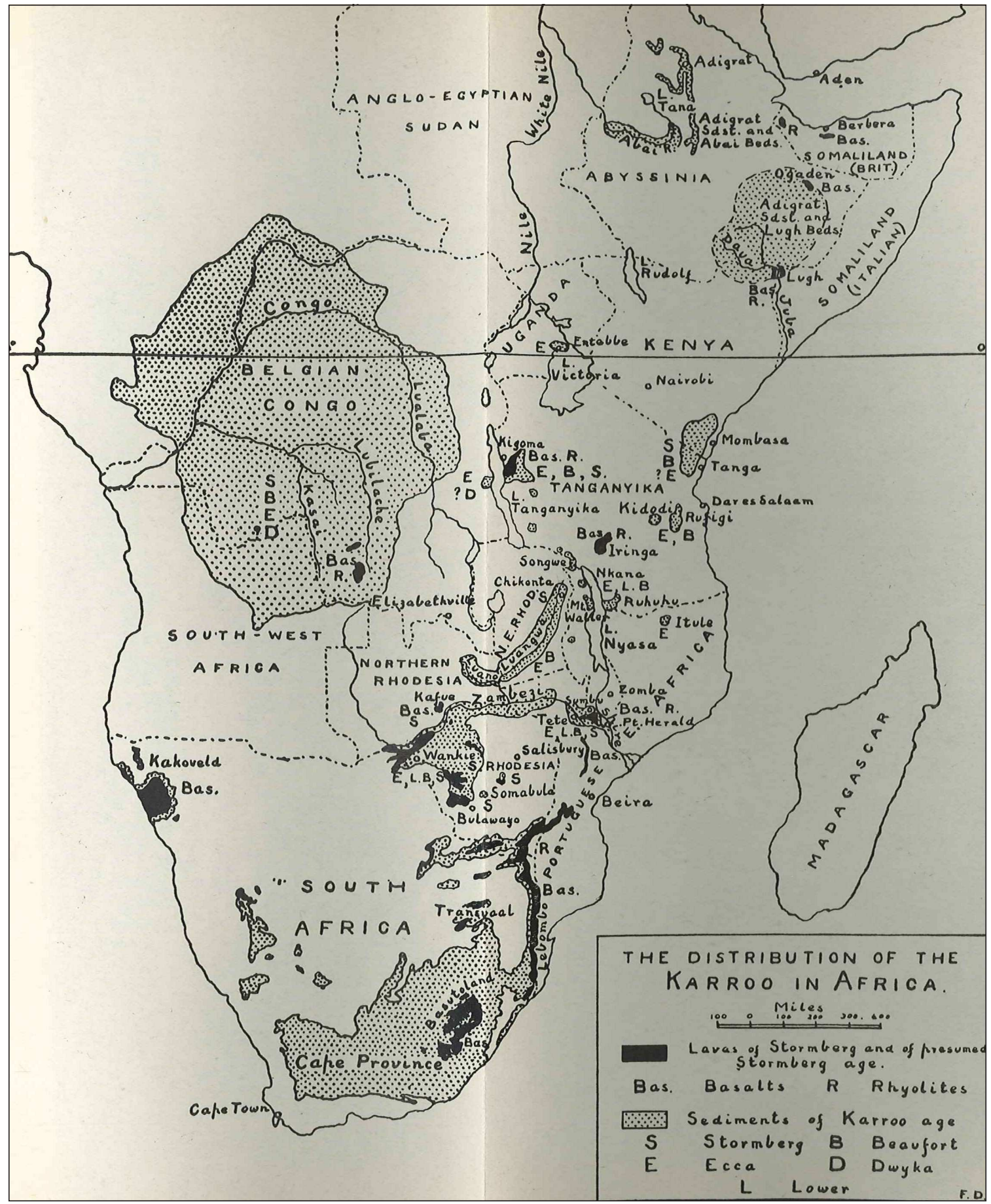

Figure 13. Distribution of the Karroo in Africa (F. Dixey). 
instance, the sedimentary strata so characteristic of this system in South Africa, which consisted of layers of sandstone and lutite, with mantles of coal, are identical to others in South America. Given the interest awakened at the IGC, an International Commission for the correlation of the Karroo System (Gondwana) was established, presided over by Arthur Williams Rogers (1872-1946) of Pretoria.

\section{The genesis of petroleum}

With the development of the internal combustion engine there was a substantial increase in the number of vehicles and grew from a few thousand at the beginning of the twentieth century to twenty million in 1920. Besides, during World War I (1914-1918) traditional cavalry gave way to 'motorized cavalry', to gain speed and mobility. There also came on the scene, on a large scale, tanks, aircraft and new types of ships, as well as submarines, making oil a strategic material, the provision of which needed to be assured. Due to this urgent demand of oil, exploration campaigns intensified, leading to the discovery of new oil fields: Mashed Suleiman (Persia, today known as Iran, in 1908), Alberta (Canada, towards 1909), Tampico (Mexico, in 1910), Venezuela (1922), as well as others in USA and Europe. All this exploratory and extractive activity led to the foundation, in 1917, of the American Association of Petroleum Geologist (AAPG) in Tulsa, Oklahoma. Oil consumption was such that some thought that reserves could finish in twenty years.

At the beginning, prospectors looked for signs of hydrocarbons at the surface (liquid and gas emanations, rocks with impregnations of asphalt, etc.), as well as zones with deposits of sulphur, because it was thought that there was an association between sulphur and oil. In this way, it was prospected in the Trias because the classic sulphate (gypsum, anhydrite) can transform into sulphur and calcite in the presence of oil. In the same way, there was research on particular formations such as the Permian (because there was oil in the Russian city of Perm-from which derives the term Permian). It was during the 1920s that geophysics (through the use of electric, magnetic, seismic and gravimetric methods) revealed the existence of structural traps like such as anticlines and domes. The Schlumberger brothers, from 1927 onwards, also began to study the properties of rocks (permeability, presence of liquids and others) through the geophysical analysis of soundings.

Some works on these topics were presented in this scientific session. The German geologist Johann Paul Krusch (1869-1939), President of the Geological Survey of Prussia, defended the idea that the genesis of the oil could be organic as well as inorganic. The Italian geologist Federico Sacco (1864-1948), in his communication L'origene del petrolio, pointed that geological investigations undertaken in Italy showed that the oil formations did not have abundant presence of fossils (quoting as an example the Argile scagliose in the Apennines) and that although signs of hydrocarbon frequently appear in formations of the Cenozoic, they could have originated at greater depth in the Mesozoic. In the same way, he claimed that hydrocarbon-rich regions were related to four types of ground: (a) Plutonic type formations such as ophiolites, which appear between the argile scagliose; (b) places with manifestations of volcanic activity, such as basalt and lava (Sicily); (c) layers of sulphur whose origin might be endogenous (Sicily); and (d) fracture-zones or diapirs that allowed the migration of the emanations of gas and oil or shale oil. Finally, Sacco defended the idea of a genetic connection between hydrocarbons and manifestations of endogenous, plutonic, volcanic and sulphurous materials (Anonymous, 1999).

For his part, the Italian geologist Ramiro Fabiani (1879-1954) presented a work on the possible origin of hydrocarbon (natural gas, oil, shale oil) of Sicily. According to his way of thinking, shale oil is associated with volcanic rocks. Evidence of hydrocarbons is localized in highly disturbed tectonic areas and particularly in faults. These tectonic disturbances affect not only the Tertiary but also the Secondary up to the known base of the Trias (basal part to the upper Trias). In the same way, he claimed that the hydrocarbons of Sicily had a deep origin and that the oil of this Italian region should be researched by means of deep bores driven through the Trias. Fabiani directed several projects on the exploration for hydrocarbons, first for the Italian state and subsequently for the oil company Agip (Fonti, 1954).

Although he did it in another scientific session, the Italian Egidio Feruglio (1897-1954) presented two works 'Origine delle Depresioni Chiuse della Regione del Golfo di San Giorgo, Patagonia' and 'Il Devonico della Regione Subandina dell'Argentina Septentrionale', both related to his first topic of research throughout his life: the regional geology, stratigraphy, paleontology, and geomorphology of Argentina, mainly for the southern part of that country, and summarized in his book Descripción Geológica de la Patagonia, commanded by the General Enrique Mosconi (1877-1940), Director of Yacimientos Petrolíferos Fiscales, YPF (Grossutti, 1997).

\section{Summary}

1. The 15th IGC in South Africa (1929) was a success in both attendance and organization, which provided a favourable basis for the next Congress: the 15th IGC in Washington (1933), which had 1,181 participants (Mendenhall, 1933).

2. The Great Depression of 1929 happened shortly after the celebration of the 15th IGC, which is why it did not affect its development.

3. The main achievement of the 15 th IGC was producing a change in people's minds as regards the theories of the continental drift of Wegener, thanks to the works of Alexander du Toit and others. As du Toit (1933) pointed out at the 15th ICG: "it has enabled a clearer idea to be gathered of the influence of so many eminent geologists upon the advancement of general geological knowledge". It can be said that the contributions of du Toit allowed a deepening in the theoretical bases of this scientific hypothesis, which celebrated its first hundred years in 2012.

4. There was much interest in mineral resources, including oil. But theories on the origin of oil were not yet well developed

5. There were also advances in the geological knowledge of Africa, for which preliminary cartography was finished shortly after the Congress. The significance of the meeting of the delegates of the African geological surveys and the creation of a subcommittee on the matter must be emphasized.

6. The publication of a new book by José García Siñeriz, with the theories and formulae associated with the different geophysical methods of exploration (previously confidential), made him the choice for President of the International Commission of Geophysics.

7. Other issues, as, for example, the origin of rift valleys, were still not well developed. 


\section{Acknowledgements}

We thank Isable Rabano (IGME), Clara Martin (Library of Madrid School of Mines) and David Oldroyd for their help in completing this paper.

\section{Bibliography}

Anonymous, 1929, El XV Congreso Geológico Internacional celebrado en Pretoria: Revista Minera, Metalúrgica y de Ingeniería, 80, pp. 425-426 and 445-446.

Anonymous 1930a, International Geological Congress. Compte Rendu of the XV Session, South Africa, 1929. Vol. I. Wallachs Ltd. Printers. Pretoria.

Anonymous, 1930b, International Geological Congress. Compte Rendu of the XV Session, South Africa, 1929. Vol. II, Scientific Communications. Wallachs Ltd. Printers. Pretoria.

Anonymous, 1947, El nuevo director del Instituto Geológico: ABC de 18 de noviembre de 1947, p. 18.

Anonymous, 1999, Federico Sacco, geologo e paleontologo. Fossano, 18641948. Quaderni delle cassa di stuio Fondazione Federico Sacco. Atti della Giornata di Studio in "Quaderno" della Fondazione Federico Sacco 14.

Arnaud, G., 1927, Le Congrès Géologique International de Madrid. Annales de Géographie, v. 36, pp. 471-472.

Ayala, F. J., Perejón, A., Jordá, L. and Puche, O., 2005, The International Geological Congress of 1926 in Spain: Episodes, v. 28, no. 1, pp. 42-47.

Bowen, N. L., 1915, The later stages of the igneous rocks: Journal of Geology, v. 23 (Supplement), pp. 1-89.

Bowen, N. L. 1928, The Evolution of the Igneous Rocks. Princeton: Princeton University Press.

Bowen, N. L., 1938, Lavas of the African rift valleys (Sector Occidental) and their tectonic setting: American Journal of Science, v. 135A, pp. 19-33.

Brandão, J. M., 2008, Missão geológica de Angola, Memórias e notícias: publicações do Departamento de Ciências da Terra e do Museu Mineralógico e Geológico da Universidade de Coimbra, v. 3, pp. 285292.

Chaves, F., 1958, Memorial of Samuel James Shand. The American Mineralogist, v. 43; pp. 317-324.

Cingolani, C.A., 2008, Alex L. du Toit (1878-1948): Semblanzas de su vida y de su aporte al conocimiento de la Geología Sudamericana: Historia de la Geología Argentina (Serie Correlación Geológica), 24; pp. 251-266.

Du Toit, A. L., 1926, The Geology of South Africa. Oliver \& Boyd. Edinburgh.

Du Toit, A. L and Reed, F. R. C., 1927, A Geological Comparison of South America with South Africa. Washington: Carnegie Institution.

Du Toit, A. L., 1933, The aftermath of the fifteenth International Geological Congress: an appreciation from South Africa: Economic Geology, v. 28, pp. 389-392.

Du Toit, A. L., 1937, Our Wandering Continents: An Hypothesis of Continental Drift. Edinburgh: Oliver \& Boyd.

Fonti, E., 1954, R. Fabiani: Curriculum e pubblicazioni: Rivista mineraria siciliana, v. 27, pp. 121-129.

Furon, R. and Lombard, J., 1964, Geological Map of Africa (1/5000000) [with] Explanatory Note: Natural Resources Research, 3. UNESCOASGA. Paris.

García Cruz, C., 2003, Más allá de la Geografía especulativa: Orígenes de la Deriva Continental: Llull, v. 26, pp. 83-107.

Gardner, J. 1940, Memorial to Giuseppe Stefanini: Proceedings of the
Geological Society of America for 1939, pp. 229-239.

Gortani, M., 1928, Ipotesi e teoria geotettoniche: Giornale di Geologia, v. 3, 3-133. Cf. Geological Magazine, Series 5, v. 7, pp. 284-285.

Grossutti, J., 1997, Egidio Feruglio: l'attivitá scientifica e gli altri doveri verso la Patria (1897-1954): Atti della giornata di studio (nel centgenari della nascita). Comune di Tavagnacco.

Hall, A. L., 1930, The Fifteenth International Geological Congress, South Africa, 1929: Nature, v. 125, pp. 69-71.

Krill, A. 2011, The chicanery of the isthmian links model: Earth Sciences History, v. 30, 200-215.

Marvin, U., 1985, The British reception of Alfred Wegener's continental drift hypothesis: Earth Sciences History, 4, pp. 138-159.

Melendez, B. and Fuster, J., 1975, Geología. Madrid: Ed. Paraninfo.

Mendenhall, W. C., 1933, The Sixteenth International Geological Congress: Science, v. 8, 247.

Molina Padrón, W. L., 2006, Comparación de los métodos 1-D y 2-D de resistividad eléctrica por medio de sondeos tipo Werner, dipolo-dipolo, y Werner-Schlumberger con la utilización de los programas DCINV, RES2DMOD y RES2DINV. Proyecto de Grado. Universidad Simón Bolívar. Sonejas.

Oldroyd, D. 2011. Arthur Holmes' paper of 1929 on convection currents within the Earth as a cause of continental drift: Episodes, v. 34, no. 1, pp. 41-50.

Pérez-Malváez, C., Bueno, A., Feria, M. and Ruiz, R., 2006, Noventa y cuatro años de la Teoría de la Deriva Continental de Alfred Lothar Wegener: Interciecia [online]. 2006, v. 31, pp. 536-543. At: http://www.scielo.org.ve /scielo.php?script=sci_arttext\&pid=

S0378-18442006000700013\&lng=es\&nrm=iso>. ISSN 0378-1844.

Sah, S. L., 2006, Encyclopaedia of Petroleum Science and Engineering. New Delhi: Kalpaz Publications.

Soloviev, Y. Y., 2007, On the 125th birthday of Dmitrii Ivanovich Mushketov (1882-1938): Stratigraphy and Geological Correlation, v. 15, pp. 443448 .

Sikes, H. L., 1926, The structure of the eastern flank of the rift valleys near Nairobi: The Geographical Journal, v. 68, pp. 385-402.

Schuchert, C., 1928, The continental displacement hypothesis as viewed by Du Toit: The American Journal of Science and Arts (Series 5), v. 16 pp. 266-274.

Tarbuck, E. J. and Lutgens, F. K., 2007, Ciencias de la Tierra: una introducción a la Geología Física (8th edn). Madrid: Pearson Educacion.

Uhlig, K., 1907, Der sogennante Groâe Ostafrikanische Graben zwischen Magad (Natron-See) und Laua ya Mueri (Manyara-See): Geographische Zeitschrift, v. 13, pp. 478-505.

Vernon, R., 2011, Alfred Williams and Leo Daft: pioneers in geophysical prospecting, in Ortíz, J. E., Puche, O., Rábano, I., and Mazadiego, L. F., eds, History of Research in Mineral Resources. Madrid: Insituto Geológico y Minero de España. Cuadernos del Museo Geominero, v. 13, pp. 289297.

Wayland, E. J., 1921, Some account of the geology of the Lake Albert rift valley: The Geographical Journal, v. 58, pp. 344-359.

Yoder, H. S., 1992, Norman L. Bowen (1887-1956), MIT class of 1912, first predoctoral fellow of the Geophysical Laboratory, Earth Sciences History, v. 11, pp. $45-55$.

Young, D. A., 2002, Norman Levi Bowen (1887-1956) and igneous rock diversity: in Oldroyd, D. ed., The Earth Inside and Out: Some Major Contributions to Geology in the Twentieth Century, Special Publication of Geological Society of London, pp. 99-111.

Young, D. A., 2003, Mind over Magma: The Story of Igneous Petrology. Princeton, Princeton University Press. 